\title{
PHENOTYPIC AND GENETIC PARAMETERS ESTIMATED FOR FRESH CORN UNDER DIFFERENT NUTRIENT AVAILABILITY ${ }^{1}$
}

\author{
CECÍLIA LEÃO PEREIRA RESENDE ${ }^{2}$, JULIANA BEZERRA MARTINS ${ }^{3}$, FELIPE RIBEIRO ILARIA ${ }^{4}$, CARLA \\ MARIANE MACHADO DOS SANTOS ${ }^{4}$, FABRICIO RODRIGUES $^{4 *}$
}

\begin{abstract}
The objective of this work was to estimate and compare phenotypic and genetic parameters after three cycles of intrapopulation recurrent selection for fresh corn grown under three nutrient availability conditions. Three experiments derived from the same population (MV-003) were conducted to assess the ability of progenies to absorb nutrients, one under adequate fertilization (control; MV-006), one under low nitrogen availability (N; MV-006N), and one under low phosphorus availability (P; MV-006P). The experiments were carried out in randomized blocks, with 64 half-sib progenies and three replications for each nutritional condition. Chlorophyll index, plant height, ear insertion, ear diameter, ear length, unhusked ear yield, and marketable husked ear were evaluated. The populations showed variability for the three nutrient availability conditions. The variability reduced after only three selection cycles; thus, evaluating a higher number of halfsib progenies, above 64, under low $\mathrm{N}$ and $\mathrm{P}$ availability is indicated. The rates used to identify the most efficient progenies in breeding programs should be close to the appropriate one, with a slow reduction after the selection cycles. The variability will be thus maintained, with a greater possibility of identifying more promising progenies. In addition, the frequency of favorable alleles increases more gradually and effectively. The $\mathrm{N}$ and $\mathrm{P}$ rate of $60 \mathrm{~kg} \mathrm{ha}^{-1}$ is not indicated as a critical level for the initial phase of the program.
\end{abstract}

Keywords: Zea mays. Recurrent selection. Low nitrogen. Low phosphorus. Half-sib.

\section{ESTIMATIVAS DE PARÂMETROS FENOTÍPICOS E GENÉTICOS EM MILHO VERDE SOB DIFERENTES DISPONIBILIDADES NUTRICIONAIS}

RESUMO - O objetivo deste trabalho foi estimar e comparar parâmetros fenotípicos e genéticos após três ciclos de seleção recorrente intrapopulacional em milho fresco sob três disponibilidades nutricionais. Três experimentos derivados de uma mesma população foram realizados para avaliar a capacidade das progênies em adquirir os nutrientes, um sob fertilização adequada (controle - MV-006), outro sob baixa disponibilidade de nitrogênio ( $\mathrm{N}-\mathrm{MV}-006 \mathrm{~N})$ e outro sob baixa disponibilidade de fósforo ( $\mathrm{P}-\mathrm{MV}-006 \mathrm{P})$. Os experimentos foram realizados em delineamento de blocos casualizados, com 64 progênies de meios-irmãos, com três repetições. Foram avaliadas as características de índice relativo de clorofila, altura da planta e inserção da espiga, diâmetro e comprimento da espiga, produtividade de espigas empalhadas e despalhadas. As populações apresentam variabilidade para as três condições de disponibilidade nutricional. A variabilidade foi muito reduzida com apenas três ciclos de seleção, sendo indicado avaliar um número maior de progênies de meiosirmãos, acima de 64, sob baixa disponibilidade de $\mathrm{N}$ e P. A dose a ser usada para identificar as progênies mais eficientes no programa de melhoramento deve estar próxima a recomendada, com uma redução lenta após os ciclos seletivos. Dessa forma, a variabilidade será mantida e com maior possibilidade de identificação de progênies mais promissoras. Além disso, a frequência de alelos favoráveis aumenta de forma mais gradual e eficaz, sendo que a dose de $60 \mathrm{~kg} \mathrm{ha}^{-1}$ de $\mathrm{N}$ e P não é indicada na fase inicial do programa, como nível crítico.

Palavras-chave: Zea mays. Seleção recorrente. Baixo nitrogênio. Baixo fósforo. Meios-irmãos.

\footnotetext{
${ }^{*}$ Corresponding author

${ }^{1}$ Received for publication in 06/26/2020; accepted in 05/10/2021.

${ }^{2}$ Postgraduate Program in Agronomy, Universidade Federal de Uberlândia, Uberlândia, MG, Brazil; cecilialprr@gmail.com - ORCID: $0000-0003-2432-4168$.

${ }^{3}$ Postgraduate Program in Genetics and Plant Breeding, Universidade Federal de Goiás, Goiânia, GO, Brazil; juliana_agro26@hotmail.com - ORCID: 0000-0002-6291-8912.

${ }^{4}$ Department of Plant Breeding, Universidade Estadual de Goiás, Ipameri, GO, Brazil; ilariafelipe@gmail.com - ORCID: 0000-0003-08151826, carlamr1@hotmail.com-ORCID: 0000-0003-1471-0970, fabricio.rodrigues@ueg.br-ORCID: 0000-0002-6133-6363.
} 


\section{INTRODUCTION}

Corn is an important crop in Brazil, the midwest region of the country is responsible for the largest planted area, approximately 8,524 thousand hectares and the highest mean yields $\left(6,095 \mathrm{~kg} \mathrm{ha}^{-1}\right)$, as in the state of Goiás, which has a mean yield of $6,805 \mathrm{~kg} \mathrm{ha}^{-1}$ (CONAB, 2020).

Despite the national and state importance of this crop, few corn cultivars intended for fresh consumption are available in Brazil, which makes it impossible for farmers to meet demand and all market niches (RODRIGUES et al., 2018). In addition, there is a low technological investment on this special seed market, which represents a small part of the corn seed market; however, fresh corn ears have high added value and high profitability.

High productivity is linked to soil fertility conditions; however, the appropriate fertilizer rates vary in the literature according to soil type, crop, management, market niche, and local edaphoclimatic conditions, which affect the plant development; in addition, studies have prioritized proper and sustainable applications (PAIVA et al., 2012). This indicates that seeds should be produced for each specific production condition, considering the technology level adopted, to meet this market demand.

Considering the nutrient requirements of corn plants, nitrogen $(\mathrm{N})$ is among the most limiting nutrients for productivity, which is affected by the soil $\mathrm{N}$ availability and plant development stage (SCHIAVINATTI et al., 2011). The application of inadequate $\mathrm{N}$ rates may decrease grain yield in $10 \%$ to $22 \%$. Only half the applied nitrogen fertilizer is used by the plants in tropical soils, the remainder is lost by volatilization, leaching, or other causes (REPKE et al., 2013).

Phosphorus (P) is a scarce nutrient in many soils worldwide due to its low natural availability, especially in tropical regions with weathered soils. $\mathrm{P}$ deficiency decrease the metabolism, biomass, and size of plant organs, mainly leaves and roots, affecting the productivity (COIMBRA et al., 2014). Many crop systems require frequent $\mathrm{P}$ applications; thus, relatively high quantities are required to ensure high yields, which increase production costs and prices of $\mathrm{P}$ because of its worldwide scarcity (RODRIGUES et al., 2014).

Thus, developing cultivars adapted to soils with low mineral nutrients is an economically viable and ecologically sustainable option to ensure higher productivity in low input agricultural systems (RAO et al., 2016). This can be achieved by selecting genotypes with superior performance under these conditions, since studies have indicated the existence of genetic variability for plants grown under low $\mathrm{N}$ (DOVALE et al., 2012; HEINZ et al., 2019), and P (MEIRELLES et al., 2016; LUO et al., 2019) availability.

Intrapopulation recurrent selection among plant breeding methods applied to corn. It is an interesting strategy for long-term improvement of valuable traits in a base population and gradually increase the frequency of favorable alleles, without losing genetic variability (RIBEIRO et al., 2016). Intrapopulation selection has been used because of its simplicity and applicability to many characters, using half-sib progeny, which is the most interesting and used procedure to obtain more productive cultivars (HEINZ et al., 2012).

In this context, this objective of this work was to estimate and compare genetic and phenotypic parameters for the selection of half-sib progenies of fresh corn under adequate fertilization conditions and under low $\mathrm{N}$ and $\mathrm{P}$ availability.

\section{MATERIAL AND METHODS}

The experiment was conducted at Universidade Estadual de Goiás, unity Ipameri-GO, during the summer, after three selection cycles (Cycle 1, 2011/2012; Cycle 2, 2013/2014; and Cycle 3, 2015/2016).

The populations recruited were from the base population MV-003, which formed the populations MV-006, MV-006N and MV-006P that went through three selection cycles under appropriate fertilizer rate (control), low $\mathrm{N}$ availability (low N) and P (low P), respectively. The population $\mathrm{MV}-003$ is from a complex cross between two imported sweet corn hybrids (CN19-50 and $\mathrm{CN}$ 23-50) and an experimental double hybrid (HD17) developed for the extraction of populations, one to produce fresh corn (MV-002 x HD17), which was the base population for MV-003 and another for sweet corn, containing the sugary allele $(s u)$, MVD-002, which was developed for another program, according to the flowchart shown in Figure 1.

Considering the demand of the corn consumer market, plants were selected for ear diameter $(>4 \mathrm{~cm})$, length $(>18 \mathrm{~cm})$, and sanity, mainly for tolerance to pathogens such as Ustilago maydis, which presented a high incidence in these population (Figure 1, Item IV). Subsequently, a backcross with the experimental hybrid (HD17) was needed to reduce the inoculum in the population (Figure 1, Item III) and restore the sanity, thus obtaining progenies that started the breeding program for low nutrient availability. 


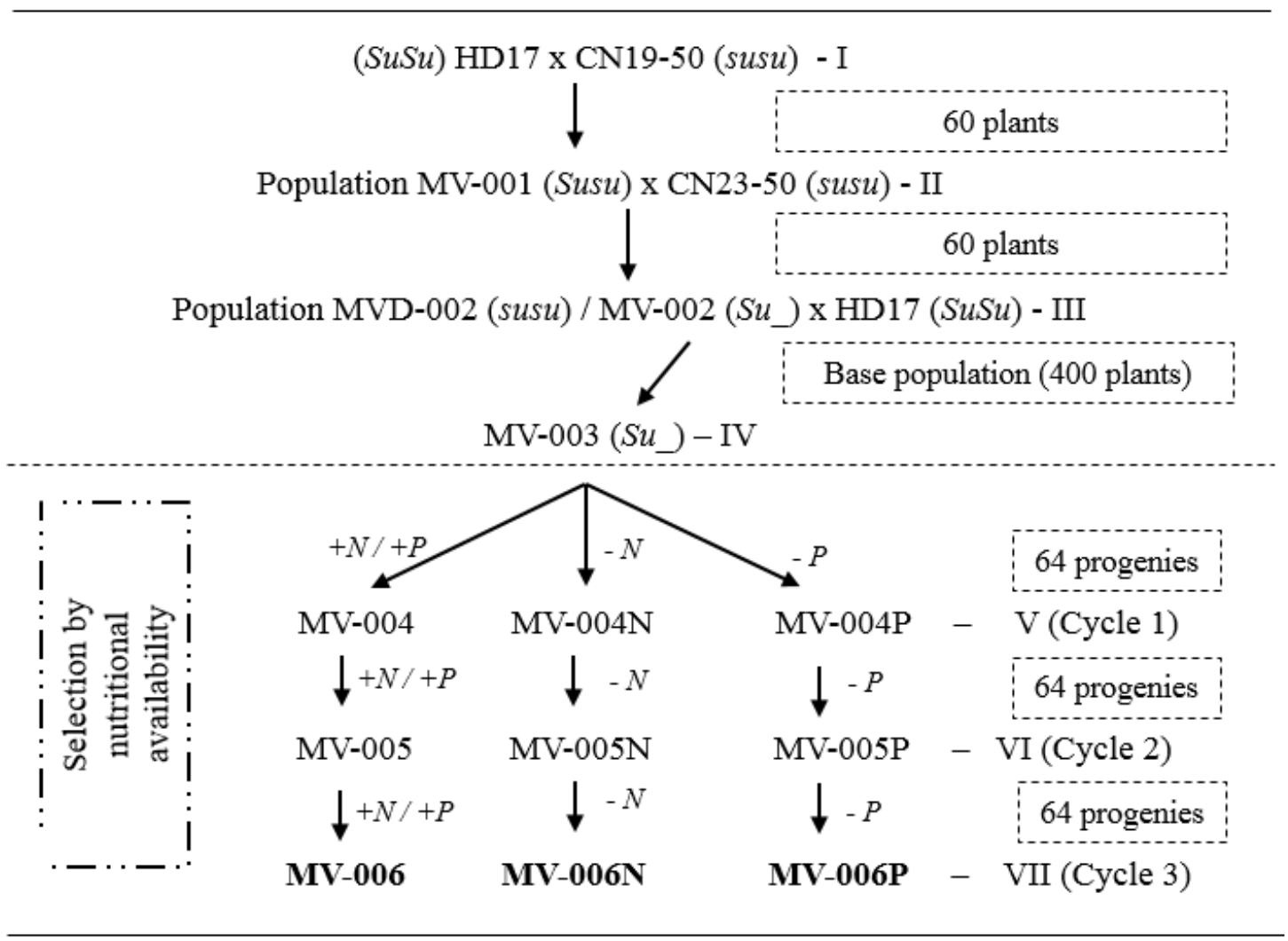

Figure 1. Flowchart of the hybridization and breeding program selection phases for the development of the population MV003 and subsequent cycles of intrapopulation recurrent selection of half-sib progenies for each nutrient availability (control, MV-006; low nitrogen availability, MV-006N; and low phosphorus availability, MV-006P).

Subsequently, three cycles of intrapopulation recurrent selection of half-sib progenies, with a selection intensity of $30 \%$, were carried out using ears harvested at $\mathrm{R}_{6}$ stage (selection), with recombination and restoration of balance between crop seasons (NASS et al., 2001). The seeds were harvested at the stage of complete physiological maturation, the central grains of healthy ears were collected, sun dried, and separated by progenies in $600 \mathrm{ml}$ pet bottles, which were stored in a cold chamber.

Three experiments were carried out in a randomized block design with 64 half-sib progenies and three replications under adequate fertilization, and low $\mathrm{N}$ and $\mathrm{P}$ availability (2015/2016 crop). The experimental plots consisted of two 4 meter rows, three plants per meter, and spacing of $0.5 \mathrm{~m}$ between rows, with an evaluating area of $4 \mathrm{~m}^{2}$.

The soil was prepared in a conventional system, with plowing, two harrowings; soon later, a cultivator was used to open the sowing furrows. The soil used was classified as a dystrophic Red-Yellow Latosol of medium texture and fertilized according to results of chemical analysis (Table 1), considering the amounts of nitrogen $\left[60 \mathrm{~kg} \mathrm{ha}^{-1}\right.$ of N - Low N (20 $\mathrm{kg}$ at sowing $+40 \mathrm{~kg}$ as topdressing)] and phosphorus $\left(60 \mathrm{~kg} \mathrm{ha}^{-1}\right.$ of $\mathrm{P}_{2} \mathrm{O}_{5}$ - Low $\left.\mathrm{P}\right)$ for the populations under low nutrient availability.

Table 1. Chemical attributes of the soil $0-20$ and $20-40 \mathrm{~cm}$ layers after liming and full fertilizer application in the 2011/2012 crop season.

\begin{tabular}{|c|c|c|c|c|c|c|c|c|c|c|}
\hline Soil & $\mathrm{pH}$ & $\overline{\mathrm{OM}}$ & $\mathrm{P}_{\text {resin }}$ & $\mathrm{H}+\mathrm{Al}$ & $\mathrm{Al}^{3+}$ & $\mathrm{K}^{+}$ & $\mathrm{Ca}^{2+}$ & $\mathrm{Mg}$ & CEC & BS \\
\hline & $\mathrm{CaCl}_{2}$ & $\mathrm{~g} \mathrm{dm}^{-3}$ & $\mathrm{mg} \mathrm{dm}{ }^{-3}$ & & -.-- & $-\mathrm{cmo}$ & $\mathrm{m}^{-3}-$ & 0 & $=$ & $\%$ \\
\hline $0-20 \mathrm{~cm}$ & 5.6 & 29.7 & 29.9 & 2.0 & 0.0 & 0.83 & 5.0 & 1.2 & 7.0 & 77 \\
\hline $20-40 \mathrm{~cm}$ & 5.0 & 14.2 & 3.0 & 2.0 & 0.0 & 0.57 & 1.9 & 0.6 & 3.3 & 62 \\
\hline
\end{tabular}

$\mathrm{pH}=$ active acidity; $\mathrm{OM}=$ organic matter; $\mathrm{P}=$ available phosphorus; $\mathrm{H}+\mathrm{Al}=$ potential acidity; $\mathrm{Al}=$ exchangeable acidity; $\mathrm{K}=$ available potassium; $\mathrm{Ca}=$ exchangeable calcium; $\mathrm{Mg}=$ exchangeable magnesium; $\mathrm{CEC}=$ effective cation exchange capacity; $\mathrm{BS}=$ base saturation at $\mathrm{pH}_{7.0}$. 
The control environment consisted of application of $20 \mathrm{~kg} \mathrm{ha}^{-1}$ of $\mathrm{N}$ (urea), $120 \mathrm{~kg} \mathrm{ha}^{-1}$ of $\mathrm{P}_{2} \mathrm{O}_{5}$ (triple superphosphate), and $90 \mathrm{~kg} \mathrm{ha}^{-1}$ of $\mathrm{K}_{2} \mathrm{O}$ (potassium chloride) at sowing, and $100 \mathrm{~kg} \mathrm{ha}^{-1} \mathrm{~N}$ as topdressing at the $\mathrm{V}_{3}$ stage (PEREIRA FILHO, 2002) for a productivity of unhusked ears between 15 and $17 \mathrm{Mg} \mathrm{ha}^{-1}$.

The phytosanitary products were applied were methoxyphenozide $240 \mathrm{~g} \mathrm{~L}^{-1}$ (Intrepid ${ }^{\circledR}$ ) at a rate of $150 \mathrm{~mL} \mathrm{ha}^{-1}$, beta-cypermethrin (Akito ${ }^{\circledR}$ ) at a rate of $75 \mathrm{~mL} \mathrm{ha}{ }^{-1}$, which were combined with manual weeding.

The chlorophyll index (CI) was measured using a CFL1030 (SN0359) device in three fully expanded leaves of the middle part of plants at $\mathrm{V}_{\mathrm{T}}$ stage. The plant height $(\mathrm{PH} ; \mathrm{cm})$ from the ground to the apex of the plant (tassel) was measured at stage $\mathrm{R}_{3}$ using a ruler; ear insertion height $(\mathrm{EIH} ; \mathrm{cm})$ from the ground to the main ear was measured with a ruler; ear diameter (ED; $\mathrm{mm}$ ) in the middle of the ear was measured using a digital caliper, considering the mean diameter of five ears of the plot; ear length $(\mathrm{EL} ; \mathrm{cm})$ from the base to the tip of the ears was measured using a ruler, considering the mean length of five ears of the plot; unhusked ear yield (UEY) was obtained by summing of the total weight of unhusked ears in the evaluation area of each plot and converting it into $\mathrm{Mg}$ per hectare; marketable ear yield (MEY) was obtained by summing the weight of husked ears free from pests and diseases that exceeded $15 \mathrm{~cm}$ in length and diameter of $4 \mathrm{~cm}$.

The ears were harvested manually as they reached the milky grain point $\left(\mathrm{R}_{3}\right.$ stage $)$, i.e., when the grains had $70 \%$ to $80 \%$ water content, which is considered as the ideal point for commercialization, at approximately 90 days after sowing.

The experiments were analyzed separately, using the statistical model (Equation 1):

$$
Y_{i j}=m+p_{i}+b_{j}+\varepsilon(i j)
$$

where $Y_{i j}$ is the progeny $i$ in block $j ; m$ is the overall mean; $p_{i}$ is the effect of the $i^{\text {th }}$ progeny; $b_{j}$ is the effect of $j^{\text {th }}$ block; and $\varepsilon(i j)$ is the experimental error.

Then, a joint analysis of variance was carried out using the statistical model (Equation 2):

$$
Y_{i j q}=m+p_{i}+a_{q}+b_{j(q)}+p a_{(i q)}+\varepsilon i j(q)
$$

where $Y_{i j}$ is the progeny $i$ in block $j$ within the availability $q ; m$ is the overall mean; $p_{i}$ is the effect of the $i^{\text {th }}$ progeny; $a_{q}$ is the effect of $q^{\text {th }}$ availability; $b_{j}$ (q) is the effect of $j^{\text {th }}$ block within the availability $q$; $p a_{(i q)}$ is the effect of the interaction between the progeny $i$ and availability $q$; and $\varepsilon_{i j(q)}$ is the experimental error.

The accuracy was estimated according to
Resende (2002), using the Equation 3:

$$
r_{g \hat{g}=\left(1-\frac{1}{F}\right)} 1 / 2
$$

where $F$ is the $\mathrm{F}$ Test (Snedecor), the value of the ratio of variances for the effects of the progeny, associated with the analysis of variance.

The genotypic and phenotypic parameters were estimated using the procedure described by Cruz, Regazzi and Carneiro (2012), according to each nutrient availability condition, using the GENES program (CRUZ, 2016).

\section{RESULTS AND DISCUSSION}

The effect of the different nutrient availability (control, low N, and low P) was significant for most characteristics $(p \leq 0.05)$, except for plant height in the control, and ear diameter in the low $\mathrm{P}$ availability treatments (Table 2). These results showed phenotypic variability between progenies, denoting the possibility of obtaining genetic gains with selection, even under low nutrient availability.

The effect of the environment (EN), progeny (PRO), and the interaction between environment and progeny $(\mathrm{EN} \times \mathrm{PRO})$ in the joint analysis was significant for all characteristics $(\mathrm{p} \leq 0.01)$, indicating the existence of variability between the progenies for the production of fresh corn according to the nutrient availability and that the progenies should be recommended considering the nutrient availability (Table 2).

The coefficients of variation (CV) were relatively low for most characteristics, with a mean of $9.2 \%$, except for UEY and MEY, which presented a mean $\mathrm{CV}$ of $26.5 \%$ (Table 2). Therefore, experiments with low $\mathrm{N}$ availability require more attention to increase the precision for the selection and discrimination of superior progenies, since it presented a mean variation of $18.3 \%$ under these conditions, whereas $\mathrm{P}$ presented a mean $\mathrm{CV}$ of $15.0 \%$.

Silva et al. (2008) evaluated grain yield in two populations of corn (UFVM 100 and UFVM 200) grown under low $\mathrm{N}$ and found mean $\mathrm{CV}$ of $35 \%$ and $24 \%$, respectively, denoting the effect of nutritional stress on plants under low $\mathrm{N}$ availability. Meirelles et al. (2016) evaluated the responses of corn lines to $\mathrm{P}$ rates and found similar values, 19\% and $22 \%$, for plants grown under low $\mathrm{P}$ availability in two crop seasons.

According to Resende and Duarte (2007), the evaluation of genetic treatments in field experiments has two objectives: i) to infer on the genotypic values of these materials, in this case, the work to 
infer on the progenies; and ii) order them based on their genotypic values, as accurately as possible, to improve the selection process. The accuracy classes for productivity variables (UEY and MEY) of progenies in the control environment, for example, indicated high accuracy values (high or very high)
(Table 2). However, $\mathrm{N}$ is in the moderate and $\mathrm{P}$ in the high class, thus, progenies will have more satisfactory results in the selection applied to the control for $\mathrm{P}$ than $\mathrm{N}$; therefore, the option is to increase the number of replications or the number of progenies to increase the selection accuracy.

Table 2. Joint and individual analysis of variance for chlorophyll index (CI), plant height (PH), ear insertion height (EIH), ear diameter (ED), ear length (EL), unhusked ear yield (UEY), and marketable ear yield (MEY) of fresh corn, with the evaluation of 64 half-sib progenies, under three nutrient availability conditions.

\begin{tabular}{|c|c|c|c|c|c|c|c|c|c|}
\hline EN & SV & $\mathrm{DF}$ & CI & PH & EIH & ED & EL & UEY & MEY \\
\hline \multirow{5}{*}{$\begin{array}{l}\overline{0} \\
\text { 苛 }\end{array}$} & PRO & 63 & $30.5^{* *}$ & $143.9^{\text {n.s. }}$ & $112.9^{* *}$ & $0.8^{* *}$ & $6.7^{* *}$ & $2754614.2^{* *}$ & $1377390.3^{* *}$ \\
\hline & Block & 2 & 257.0 & 6383.5 & 1766.4 & 31.6 & 24.1 & 2880765.3 & 3115216.3 \\
\hline & Error & 126 & 7.8 & 151.2 & 33.9 & 0.2 & 1.4 & 544729.3 & 288314.5 \\
\hline & CV (\%) & & 5.6 & 5.8 & 4.4 & 9.0 & 6.9 & 13.7 & 19.5 \\
\hline & $r_{g \hat{g}}$ & & 0.9 & - & 0.8 & 0.9 & 0.9 & 0.9 & 0.8 \\
\hline \multirow{5}{*}{$\begin{array}{l}Z \\
z \\
0 \\
3 \\
3\end{array}$} & PRO & 63 & $64.6^{* *}$ & $421.8^{*}$ & $239.9^{* *}$ & $0.3^{*}$ & $5.6^{*}$ & $3675044.6^{*}$ & $1194656.0^{* *}$ \\
\hline & Block & 2 & 836.8 & 5067.6 & 1649.7 & 1.6 & 6.5 & 12194966.4 & 11369708.1 \\
\hline & Error & 126 & 31.5 & 282 & 111.2 & 0.2 & 3.8 & 2432464.4 & 734673.1 \\
\hline & CV (\%) & & 13.4 & 9.5 & 12.1 & 8.9 & 13.5 & 32.1 & 38.5 \\
\hline & $r_{g \hat{g}}$ & & 0.7 & 0.6 & 0.7 & 0.6 & 0.5 & 0.6 & 0.6 \\
\hline \multirow{5}{*}{$\begin{array}{l}0 \\
3 \\
0 \\
3\end{array}$} & PRO & 63 & $40.1^{* *}$ & $394.3^{* *}$ & $228.8^{* *}$ & $0.2^{\mathrm{ns}}$ & $6.0^{* *}$ & $4001906.8^{* *}$ & $1462000.9^{* *}$ \\
\hline & Block & 2 & 645.8 & 528.1 & 423.7 & 0.4 & 4.0 & 5369362.9 & 4533335.2 \\
\hline & Error & 126 & 23.9 & 227.1 & 84.9 & 0.2 & 2.4 & 1419331.3 & 444270.7 \\
\hline & $\mathrm{CV}(\%)$ & & 11.3 & 8.4 & 10.6 & 8.6 & 10.6 & 25.0 & 30.1 \\
\hline & $r_{g \hat{g}}$ & & 0.6 & 0.6 & 0.8 & - & 0.8 & 0.8 & 0.8 \\
\hline \multirow{7}{*}{ 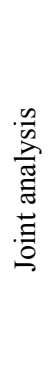 } & EN & 2 & $1108.8^{* *}$ & $4790.9^{* *}$ & $1002.0^{* *}$ & $155.8^{* *}$ & $484.4^{* *}$ & $271009092.3^{* *}$ & $180697707.9^{* *}$ \\
\hline & PRO & 63 & $87.4^{* *}$ & $603.9^{* *}$ & $471.8^{* *}$ & $1.6^{* *}$ & $9.0^{* *}$ & $6794029.6^{* *}$ & $1828826.0^{* *}$ \\
\hline & $\mathrm{EN} \times \mathrm{PRO}$ & 126 & $66.8^{* *}$ & $401.5^{* *}$ & $274.6^{* *}$ & $1.3^{* *}$ & $6.6^{* *}$ & $4379644.3^{* *}$ & $1533717.2^{* *}$ \\
\hline & Block & 2 & 109.5 & 900.1 & 648.2 & 2.5 & 23.9 & 2177768.1 & 5351573.4 \\
\hline & Error & 382 & 31.9 & 216.2 & 122.9 & 0.3 & 4.0 & 1769247 & 866473.0 \\
\hline & CV (\%) & & 12.6 & 7.7 & 11.5 & 9.7 & 12.4 & 23.0 & 33.6 \\
\hline & $r_{g \hat{g}}$ & & 0.5 & 0.6 & 0.6 & 0.4 & 0.5 & 0.6 & 0.4 \\
\hline
\end{tabular}

$\mathrm{EN}=$ environment; PRO = progenies; $\mathrm{SV}=$ source of variation; DF - degreess of freedom; ${ }^{*}=$ significant at $5 \%$ probability, ${ }^{* *}=$ significant at $1 \%$ probability, and ${ }^{\mathrm{ns}}=$ not significant by the $\mathrm{F}$ test; $\mathrm{CV}(\%)=$ coefficient of variation; $r_{g} \hat{g}=$ selection accuracy.

Most of the observed variation in $\sigma_{p h}^{2}$ was due to $\sigma_{g}^{2}$, denoting the possibility of selecting superior progenies based on the phenotype, 76 and $52 \%$, on average, for the control and low $\mathrm{P}$ environments, respectively (Table 3). However, under low $\mathrm{N}$ availability, these values decrease to $41 \%$, except for CI (51\%) and EIH (54\%).

Defining the appropriate rate for the formation of segregating populations and subsequent selection is among the barriers for selection under low nutrient availability, since plants should have the effect of the nutritional stress without causing high damage to the ears or an increase in pests and diseases. These damages would decrease the potential for the consumer market due to the low product quality and, in addition, low variability for further selection cycles due to the combination of 
different stresses (biotic and abiotic), making it difficult the selection of progenies based on only one stress.

Araújo et al. (2014) evaluated the marketable ear yield of the hybrid AG1051 and found decreases of approximately $70 \%$ in yield when using the $\mathrm{N}$ rate of $50 \mathrm{~kg} \mathrm{ha}{ }^{-1}$, when compared to the $\mathrm{N}$ rate of $150 \mathrm{~kg} \mathrm{ha}^{-1}$. This indicates that the reductions in fertilizer rates should be slower, or closer to that used for crops, over the selection cycles. In this case, selecting populations by increasing the nutrient rates and using a higher number of progenies would enable a greater genotypic variability and less effect of the interaction between genotype and environment $(\mathrm{G} \times \mathrm{E})$ under low nutrient availability.

Considering the $\mathrm{CV}_{\mathrm{g}}$ values and, mainly, on the $\mathrm{CV}_{\mathrm{g}}$ to $\mathrm{CV}_{\mathrm{e}}$ ratio $(b)$, this methodology should not be discarded for $\mathrm{P}$ despite it is a more promising and satisfactory result (Table 3). However, a low number of progenies was used to improve the accuracy of the data and make the evaluation process possible, since the fresh product is highly perishable and many evaluations were needed.

The $b$ values in the control environment were low $(b<1.0), 1.12$ to 1.16 , except for EL, UEY and MEY; a $b$ value higher than 1 denotes a high magnitude of the genetic component for the characteristics and are favorable for the selection (Table 3). The $b$ values were below 0.62 for $\mathrm{N}$ and and below 0.87 for P. Heinz et al. (2012) found $b$ values of 1.42 and 0.93 for the control and low $\mathrm{N}$ environment, respectively, when evaluating $\mathrm{N}$ use efficiency of half-sib progenies from 84 families using $40 \mathrm{~kg} \mathrm{ha}^{-1}$ of $\mathrm{N}(20 \mathrm{~kg}$ at sowing $+20 \mathrm{~kg}$ as topdressing), denoting a high chance of success with selection, even using a low $\mathrm{N}$ rate, but a higher number of progenies.

Some breeders have achieved this progress because the leaves of plants have a high $\mathrm{NO}^{3-}$ storage capacity during selection; thus, greater attention on the stay-green trait, kernel filling stage, and other mechanisms, such as the plant $\mathrm{N}$ relocation to grains and ear is required; these characteristics are complex and require high accuracy in the selection (CHEN et al., 2016; CIAMPITTI; VYN, 2011). Plant density is also a determining factor of $\mathrm{N}$ use efficiency, and the $\mathrm{CI}$ is an indirect measure of the plant $\mathrm{N}$ accumulation and an important variable for breeding programs focused on $\mathrm{N}$ efficiency, however, with high environmental effect $(b=0.59)$, as shown in Table 3 .

Table 3. Estimates of phenotypic and genotypic parameters for the variables chlorophyll index (CI), plant height (PH), ear insertion height (EIH), ear diameter (ED), ear length (EL), unhusked ear yield (UEY), and marketable ear yield (MEY) of 64 half-sib progenies of fresh corn grown under three nutrient availability (NA) conditions.

\begin{tabular}{|c|c|c|c|c|c|c|c|c|}
\hline NA & Parameters & $\mathrm{CI}$ & $\mathrm{PH}$ & EIH & ED & EL & UEY & MEY \\
\hline \multirow{5}{*}{$\begin{array}{l}\overrightarrow{0} \\
\stackrel{\Xi}{0}\end{array}$} & $\sigma_{p h}^{2}$ & 10.17 & - & 37.62 & 0.25 & 2.24 & 918204.72 & 459130.11 \\
\hline & $\sigma_{e}^{2}$ & 2.60 & - & 11.30 & 0.08 & 0.46 & 181576.45 & 96104.82 \\
\hline & $\sigma_{g}^{2}$ & 7.56 & - & 26.32 & 0.17 & 1.79 & 736628.28 & 363025.29 \\
\hline & $\mathrm{CV}_{\mathrm{g}}$ & 5.49 & - & 3.92 & 7.59 & 7.93 & 15.88 & 22.39 \\
\hline & $\mathrm{CV}_{\mathrm{g}} / \mathrm{CV}_{\mathrm{e}}$ & 0.98 & - & 0.88 & 0.84 & 1.14 & 1.16 & 1.12 \\
\hline \multirow{5}{*}{$\begin{array}{l}Z \\
z \\
3 \\
\end{array}$} & $\sigma_{p h}^{2}$ & 21.54 & 140.59 & 79.97 & 0.09 & 1.88 & 1225014.85 & 398218.68 \\
\hline & $\sigma_{e}^{2}$ & 10.50 & 94.01 & 37.08 & 0.06 & 1.26 & 810821.47 & 244891.02 \\
\hline & $\sigma_{g}^{2}$ & 11.04 & 46.58 & 42.89 & 0.03 & 0.62 & 414193.38 & 153327.66 \\
\hline & $\mathrm{CV}_{\mathrm{g}}$ & 7.91 & 3.84 & 7.49 & 3.79 & 5.44 & 13.26 & 17.61 \\
\hline & $\mathrm{CV}_{\mathrm{g}} / \mathrm{CV}_{\mathrm{e}}$ & 0.59 & 0.41 & 0.62 & 0.42 & 0.40 & 0.41 & 0.46 \\
\hline \multirow{5}{*}{$\begin{array}{l}0 \\
3 \\
0 \\
0 \\
3\end{array}$} & $\sigma_{p h}^{2}$ & 13.35 & 131.42 & 76.26 & - & 2.01 & 1333968.94 & 487333.64 \\
\hline & $\sigma_{e}^{2}$ & 7.97 & 75.71 & 28.29 & - & 0.79 & 473110.42 & 148090.22 \\
\hline & $\sigma_{g}^{2}$ & 5.39 & 55.70 & 47.97 & - & 1.22 & 860858.51 & 339243.42 \\
\hline & $\mathrm{CV}_{\mathrm{g}}$ & 5.39 & 4.16 & 7.97 & - & 7.58 & 19.43 & 26.31 \\
\hline & $\mathrm{CV}_{\mathrm{g}} / \mathrm{CV}_{\mathrm{e}}$ & 0.47 & 0.50 & 0.75 & - & 0.72 & 0.78 & 0.87 \\
\hline
\end{tabular}

- = no significant difference between the progenies; $\sigma_{p h}^{2}=$ phenotypic variability; $\sigma_{e}^{2}=$ environmental variability; $\sigma_{g}^{2}=$ genotypic variability; $\mathrm{CV}_{\mathrm{g}}=$ coefficient of genetic variation; $\mathrm{CV}_{\mathrm{g}} / \mathrm{CV}_{\mathrm{e}}=$ genetic to environmental variation ratio. 
Li et al. (2021) evaluated the performance and correlation between traits of 380 divergent lines (divided into groups and subgroups) of corn plants grown under high and low soil $\mathrm{P}$ availability, and reported that biomass traits, as shoot dry weight, and morphological traits, as plant height, can be indirectly used to select more tolerant lines to low $\mathrm{P}$ availability and that mechanisms within the same group presented differences for grain yield. In the present work, progenies under low $\mathrm{P}$ availability presented low genetic variability $(b=0.47)$ and heritability $\left(\mathrm{h}^{2}=42 \%\right)$, which can make the selection program unfeasible (Tables 3 and 4).

Table 4. Lower limit (LL), upper limit (UL), original population average $\left(\mathrm{X}_{\mathrm{o}}\right)$, selected population average $\left(\mathrm{X}_{\mathrm{s}}\right)$, heritability $\left(\mathrm{h}^{2}\right)$, selection gain $(\mathrm{SG})$, and selection gain percentage $(\mathrm{SG} \%)$ in fresh corn populations under three nutrient availabilit (NA) conditions.

\begin{tabular}{|c|c|c|c|c|c|c|c|c|}
\hline NA & Variable & LL & UL & $X_{o}$ & $\mathrm{X}_{\mathrm{s}}$ & $\mathrm{h}^{2}$ & SG & SG\% \\
\hline \multirow{7}{*}{$\begin{array}{l}\overline{\text { Dे }} \\
\text { 音 }\end{array}$} & $\mathrm{CI}$ & 36.60 & 59.90 & 50.90 & 51.05 & 74.38 & 0.11 & 0.22 \\
\hline & $\mathrm{PH}$ & - & - & 200.78 & - & - & - & - \\
\hline & EIH & 89.40 & 141.00 & 95.54 & 114.54 & 69.97 & 13.29 & 13.91 \\
\hline & ED & 3.80 & 6.90 & 5.48 & 5.98 & 67.85 & 0.34 & 6.19 \\
\hline & EL & 12.20 & 21.30 & 16.84 & 18.20 & 79.68 & 1.08 & 6.43 \\
\hline & UEY & 5166.00 & 11219.00 & 7010.69 & 9828.98 & 80.22 & 2260.83 & 32.25 \\
\hline & MEY & 4028.10 & 8097.40 & 6011.97 & 7106.50 & 79.07 & 865.44 & 14.40 \\
\hline \multirow{7}{*}{$\begin{array}{l}z \\
z \\
z \\
0 \\
\end{array}$} & CI & 21.30 & 52.80 & 42.03 & 44.04 & 51.26 & 1.03 & 2.45 \\
\hline & PH & 116.00 & 208.80 & 177.52 & 182.06 & 33.13 & 1.51 & 0.85 \\
\hline & EIH & 41.00 & 136.33 & 87.47 & 91.62 & 53.63 & 2.23 & 2.55 \\
\hline & ED & 3.50 & 5.70 & 4.62 & 4.79 & 35.11 & 0.06 & 1.35 \\
\hline & EL & 8.90 & 20.00 & 14.44 & 15.34 & 32.83 & 0.30 & 2.05 \\
\hline & UEY & 900.10 & 9789.40 & 4853.78 & 6029.48 & 33.81 & 397.52 & 8.19 \\
\hline & MEY & 642.86 & 5620.50 & 2223.56 & 2719.04 & 38.50 & 190.78 & 8.58 \\
\hline \multirow{7}{*}{$\begin{array}{l}0 \\
0 \\
0 \\
0\end{array}$} & $\mathrm{CI}$ & 20.70 & 58.00 & 43.08 & 45.28 & 40.36 & 0.89 & 2.06 \\
\hline & $\mathrm{PH}$ & 91.80 & 199.20 & 179.32 & 186.15 & 42.39 & 2.90 & 1.62 \\
\hline & EIH & 44.20 & 123.40 & 86.86 & 89.28 & 62.91 & 1.52 & 1.76 \\
\hline & ED & - & - & 4.63 & - & - & - & - \\
\hline & EL & 6.50 & 19.30 & 14.60 & 15.59 & 60.71 & 0.60 & 4.12 \\
\hline & UEY & 1010.70 & 8578.90 & 4775.63 & 5898.61 & 64.53 & 724.70 & 15.17 \\
\hline & MEY & 443.56 & 3292.56 & 2214.07 & 2672.40 & 69.61 & 319.06 & 14.41 \\
\hline
\end{tabular}

${ }^{-}=$no significant difference between progenies; $\mathrm{CI}=$ chlorophyll index; $\mathrm{PH}=$ plant height; $\mathrm{EIH}=$ ear insertion height; $\mathrm{ED}=$ ear diameter; EL = ear length; UEY = unhusked ear yield; and MEY = marketable ear yield.

Van Bueren and Struik (2017) reported that N use efficiency is variable and genotypes evaluated under high and low $\mathrm{N}$ availability can produce cultivars adapted to both conditions, i.e., efficient and responsive to application of N. However, the G $\times$ E interaction is significant and the responses in this condition in crop systems are complex and makes the selection for this stress difficult. The results confirmed these responses, considering the selected population and genetic gains found for the progenies (Table 4).
The gain percentages (SG\%) in the control environment were approximately 3-fold higher $(12.3 \%)$ than those for the $\mathrm{N}$ treatment $(3.7 \%)$, confirming the difficulty of finding progenies with higher soil nutrient absorption capacity. The mean gains obtained for $\mathrm{P}$ were $6.5 \%$, indicating less complexity and higher possibility to find genotypes for this condition.

The lowest rate, or critical level for breeding programs focused on tolerance to abiotic stresses and $\mathrm{N}$ and $\mathrm{P}$ use efficiency, should be determined to 
select cultivars more adapted to these environments, because the trait heritability decreases as the as stress is increased, which decreases the variability and make the recurrent selection process unfeasible. Godoy et al. (2013) reported that the $\mathrm{N}$ rate of $60 \mathrm{~kg} \mathrm{ha}^{-1}$ is an adequate critical level to classify corn genotypes; however, after a low number of cycles, the variability tends to be exhausted, as found for $\mathrm{N}$; and that this rate generates almost no variability to continue the program (Table 4).

Woli et al. (2016) reported that grain yield and $\mathrm{N}$ use efficiency in hybrids increased from 1960 top 2000, but not during the 1980s and 1990s, and the ability of plant to absorb nitrogen presented a slightly increase during this period. This may be due to the low genetic gain, as found for the variables UEY and MEY, 8.2 and 8.6\% (Table 4). DoVale et al. (2012) evaluated genetic effects of traits associated with nitrogen use efficiency in corn and found variability between groups and efficiencies; they concluded that additive genetic effects were important for traits related to efficiency and that parents contributed in differently to the transmission of alleles; thus, they recommended intrapopulation methods.

Mendes et al. (2015) evaluated the genetic control of characteristics related to phosphorus $(\mathrm{P})$ use efficiency in tropical corn and found predominance of dominance effects. This indicates that the plant breeding should be focused on obtaining hybrids to explore heterosis for characteristics related to $\mathrm{P}$ efficiency; thus, the interpopulation method would be more appropriated than intrapopulation. According to Guedes et al. (2014), this would also be the most appropriate method for nitrogen, since nonadditive genetic effects are the most promising for nitrogen use efficiency. Heritability values of 0.79 and 0.88 were found by Mendes et al. (2015) for grain yield under low and high $\mathrm{P}$ availability, respectively; and Guedes et al. (2014) found gains of approximately 92 and 72 in two locations for $\mathrm{N}$, denoting higher gains and higher results than those found for fresh corn, as found in the present work for productivity (Table 4).

The estimates of lower (LL) and upper (UL) limits showed variability, especially for yields, which were high in some progenies. When compared to the original population means $\left(\mathrm{X}_{\mathrm{o}}\right)$, the variabilities were $60 \%, 102 \%$, and $80 \%$ higher for UEY, and $1.4 \%, 153 \%$, and $3.5 \%$ higher for MEY, based on the progenies with the highest performance in the control, low $\mathrm{N}$, and low $\mathrm{P}$, respectively. Thus, there are progenies with potential higher than expected, but a low number of them and small genetic gains for each selection cycle, which is possibly due to the low frequencies of alleles related to nutrient use efficiencies and the low variability from crosses in the formation of the MV03 base population (Table 4 and Figure 1).

This was also found for the heritability values; $90 \%$ and $31 \%$ more chance of success in the selection, with gains of 923 and $736 \mathrm{~kg} \mathrm{ha}^{-1}$ were found when comparing the gains of the control to the selection under low availability of $\mathrm{N}$ and $\mathrm{P}$, respectively, which enables to achieved productivity improvements over few cycles. The chances of success with selection were more promising for the control environment (average $\mathrm{h}^{2}=75$ ) $>$ low $\mathrm{P}$ (average $\left.\mathrm{h}^{2}=57\right)>$ low $\mathrm{N}\left(\right.$ average $\left.\mathrm{h}^{2}=40\right)$, indicating that the criteria should follow these conditions, and the use of a larger number of variables linked to efficiency, thus generating a greater accuracy in recurrent selection (Table 4).

The base population (MV-003) that generated the three advanced fresh corn populations has a large amount of sweet corn alleles (Figure 1). The heritability presented similar results to those found by Abe and Adelegan (2019) for super sweet corn $(s h 2)$ in a tropical germplasm, which were $65.9,66.1$, $67.2,68.7$, and $66.7 \%$, for EIH, ED, EL, UEY, and $\mathrm{MEY}$, respectively. In the present work, the values followed the same order, with $69.9,67.8,79.7,80.2$, and $79.1 \%$, respectively, in the control environment (Table 4). Abe and Adelegan (2019) reported difficulty in finding values of this magnitude due to the narrow genetic basis of the germplasms, but with possibility of obtaining promising genotypes, as in the present work.

Khan et al. (2018) described how a balanced addition of N-P-K to the soil increases the efficiency of $\mathrm{P}$, and reported that the addition of manure does not result in a higher $\mathrm{P}$ absorption by the plant, which may boost the selection by nutrient combinations, without the addition of organic compounds to increase the plant efficiency, and promote a higher $\mathrm{G} \times \mathrm{E}$ interaction. According to their results, even if the stress occurs for only one nutrient, the selection process has a high $\mathrm{G} \times \mathrm{E}$ interaction, since there was an Indian summer in the beginning of the development, and can alter the selection process for more efficient plants for water use and not for the nutrient being evaluated, decreasing the frequency of favorable alleles related to efficiency in the population.

Schlegel and Havlin (2017) reported that, over 19 years, grain yield increased in $20 \%$ for $\mathrm{P}$, $103 \%$ for $\mathrm{N}$, but up to $225 \%$ for $\mathrm{N}$ and $\mathrm{P}$ applied combined, when compared to controls without fertilize applications. Thus, selection should be focused on one nutrient, with caveats between nutrient combinations due to the strong interaction between N-P-K in plant development, and absorption and use of these nutrients.

Resende et al. (2019) report the commercialization form (husked or unhusked), the nutritional stress intensity (total or partial), and the crop season should be analyzed to classify the corn hybrid efficiency and responsiveness to $\mathrm{N}$ and $\mathrm{P}$. This is because the Indian summer that occurred in one of the harvests, and a change in the classification 
of hybrids, which in this case could occur between the progenies, alternating alleles during selection processes.

Zhang et al. (2015) evaluated 826 corn accessions (580 tropical and 246 temperate) under low $\mathrm{P}$ availability conditions and found that tropical accessions have higher tolerance and are more efficient than temperate ones, which may be related to the lower number of accessions tested from one group compared to the other. They also reported that hybridization with tropical parents is indicated for selection focused on identifying more adapted progenies that have more tolerance characteristics and mechanisms to nutritional stress. In the present work, the hybrids (parents) were from tropical and temperate conditions, which increases the chances of finding more adapted progenies and mechanisms from different groups. However, Zhang et al. (2015) reported that crossings between tropical parents could result in more adapted mechanisms to the soils of the Cerrado biome and better development; and plant breeding for $\mathrm{N}$ and $\mathrm{P}$ use efficiency is complex because the $\mathrm{G} \times \mathrm{E}$ interaction is high possibly due to two or more abiotic stresses during the evaluation, such as water stress, due to the frequent Indian summers in the region, and because tropical and temperate genotypes have different mechanisms for efficiencies. Thus, decreases in nutrient rate should be gradual over the cycles, and a larger number of progenies should be evaluated with a wider range of variables to improve the differentiation of progenies.

Phosphorus presents a more favorable condition; a small increase in the $\mathrm{P}$ rate and number of progenies evaluated may increase the chances of success with selection for the environment under low $\mathrm{P}$ availability. Talabi, Badu-Apraku and Fakorede (2017) reported that the complexity of the selection process makes it difficult to identify superior progenies because of the direct and indirect correlation between characters and the variability in decreases and modification of alleles for water stress, thus decreasing the variability for low $\mathrm{N}$ availability, despite of the selection for this condition.

Gerhardt et al. (2017) evaluated the P use efficient in popcorn lines without $\mathrm{P}$ application at planting and found significant differences and detection of more promising lines. Spolaor et al. (2018) evaluated varieties under in high and low $P$ availability conditions without application of $\mathrm{P}$ and found significant differences and detected the most promising genotypes for each condition that can be used as a source of variability for breeding programs.

The highest difference between the experiments with grains and fresh corn is the ear quality, which should be maintained, considering the shelf-life time and commercial acceptance, denoting the importance of a gradual reduction of the nutrient rate for the maintenance of variability over the cycles, as shown by the comparison between the control and the low $\mathrm{N}$ and $\mathrm{P}$ treatments (Table 4).
The selection conducted using an appropriate rate of fertilizer (control) showed higher variability and detection of superior genotypes, even using a low number of progenies. This facilitates the plant breeding and increases the selection efficiency, with more satisfactory gains in shorter periods than the use of low nutrient availability, and increases the control over genetic gains, resulting in a higher quality of products for the fresh corn market.

\section{CONCLUSION}

The populations evaluated present variability under the three conditions of nutrient availability appropriate fertilizer rates, low nitrogen availability, and low phosphorus availability. However, the variability was almost exhausted after only three selection cycles, thus, a larger number of half-sib progenies, above 64, under low nitrogen and phosphorus availability should be evaluated.

The rate to be used to identify the most efficient progenies in the breeding program should be close to that of the recommended for the crop, with slow decreases after each selection cycle, to maintain a high variability, identify more promising progenies, and increase allele frequency more gradually and effectively, using $60 \mathrm{~kg} \mathrm{ha}^{-1}$ of nitrogen and phosphorus for the initial phase, which is not indicated as the critical level.

\section{ACKNOWLEDGEMENTS}

The authors thank the National Council for Scientific and Technological Development - CNPq and the Coordination for the Improvement of Higher Education Personnel - CAPES for providing the scholarships.

\section{REFERENCES}

ABE, A.; ADELEGAN, C. A. Genetic variability, heritability and genetic advance in shrunken-2 supersweet corn (Zea mays L. saccharata) populations. Journal of Plant Breeding and Crop Science, 11: 100-105, 2019.

ARAÚJO, R. M. et al. Resposta do milho verde à inoculação com Azospirillum brasilense e níveis de nitrogênio. Ciência Rural, 44: 1556-1560, 2014.

CHEN, K. et al. Genetic improvement in density and nitrogen stress tolerance traits over 38 years of commercial maize hybrid release. Field Crops Research, 196: 438-451, 2016.

CIAMPITTI, I. A.; VYN, T. J. A comprehensive 
study of plant density consequences on nitrogen uptake dynamics of maize plants from vegetative to reproductive stages. Field Crops Research, 121: 2$18,2011$.

COIMBRA, R. R. et al. Relação entre tolerância do milho a baixo teor de fósforo no solo e responsividade a adubação fosfatada. Bioscience Journal, 30: 332-339, 2014.

CONAB - Companhia Nacional de Abastecimento. Acompanhamento de safra brasileira: grãos, safra 2019/2020, Tabela de Levantamento - 12/05/2020. Disponível em: < https://www.conab.gov.br/infoagro/safras $>$. Acesso em: 24 jul. 2020.

CRUZ, C. D. Genes Softwaree - extended and integrated with the R, Matlab and Selegen. Acta Scientiarum, 38: 547-552, 2016.

CRUZ, C. D.; REGAZZI, A. J.; CARNEIRO, P. C. Modelos biométricos aplicados ao melhoramento genético. 4. ed. Viçosa, MG: UFV, 2012. 514 p.

DOVALE, J. C. et al. Efeitos gênicos de caracteres associados à eficiência no uso de nitrogênio em milho. Pesquisa Agropecuária Brasileira, 47: 385$392,2012$.

GERHARDT, I. F. S. et al. O. Intraspecific variability of popcorn S7 lines for phosphorus efficiency in the soil. Genetics and Molecular Research, 16: 1-14, 2017.

GODOY, C. L. et al. Methods to classify maize cultivars in use efficiency and response to nitrogen. Revista Ceres, 60: 699-705, 2013.

GUEDES, F. L. et al. Inheritance of nitrogen use efficiency in inbred progenies of tropical maize based on multivariate diallel analysis. The Scientific World Journal, 2014: 1-7, 2014.

HEINZ, R. et al. Seleção de progênies de meioirmãos de milho para eficiência no uso de nitrogênio. Revista Ciência Agronômica, 43: 731-739, 2012.

HEINZ, R. et al. Selection of parents for low nitrogen stress through the combining ability of maize partially inbred lines. Acta Scientiarum. Agronomy, 41: 1-7, 2019.

KHAN, A. et al. Phosphorus efficiency, soil phosphorus dynamics and critical phosphorus level under long-term fertilization for single and double cropping systems. Agriculture, Ecosystems \& Environment, 256: 1-11, 2018.

LI, D. et al. Dissecting the phenotypic response of maize to low phosphorus soils by field screening of a large diversity panel. Euphytica, 217: 1-12, 2021.

LUO, B. et al. Metabolite profiling and genome $\square$ wide association studies reveal response mechanisms of phosphorus deficiency in maize seedling. The Plant Journal, 97: 947-969, 2019.

MEIRELLES, W. F. et al. Análise dialélica de linhagens de milho quanto à responsividade ao fósforo e à sua eficiência de uso. Pesquisa Agropecuária Brasileira, 51: 224-232, 2016.

MENDES, F. F. et al. Genetic control of traits related to phosphorus use efficiency in tropical maize. Crop Breeding and Applied Biotechnology, 15: 59-65, 2015.

NASS, L. L. et al. Recursos Genéticos \& Melhoramento - Plantas. Ed. 1. Rondonópolis, MT: Fundação MT, 2001, 1183 p.

PAIVA, M. R. F. C. et al. Doses de nitrogênio e de fósforo recomendadas para produção econômica de milho-verde na Chapada do Apodi-RN. Revista Caatinga, 25: 1-10, 2012.

PEREIRA FILHO, I. A. O cultivo do milho verde. 1. ed. Sete Lagoas, MG: EMBRAPA Milho e Sorgo, 2002. 217 p

RAO, I. M. et al. Root adaptations to soils with low fertility and aluminium toxicity. Annals of Botany, 118: 593-605, 2016.

REPKE, R. A. et al. Eficiência da Azospirillum brasilense combinada com doses de nitrogênio no desenvolvimento de plantas de milho. Revista Brasileira de Milho e Sorgo, 12: 214-226, 2013.

RESENDE, C. L. P. et al. Agronomic efficiency of hybrids of corn to nitrogen, phosphorus and potassium targeting fresh corn. Journal of Agricultural Science, 11: 120-133, 2019.

RESENDE, M. D. V.. Genética biométrica e estatística no melhoramento de plantas perenes. 1. ed. Brasília, DF: Embrapa Informação Tecnológica, $2002,975 \mathrm{p}$

RESENDE, M. D. V. DE.; DUARTE, J. B. Precisão e controle de qualidade em experimentos de avaliação de cultivares. Pesquisa Agropecuária Tropical, 37: 182-194, 2007.

RIBEIRO, R. M. et al. Effect of recurrent selection on the variability of the UENF-14 popcorn population. Crop Breeding and Applied Biotechnology, 16: 123-131, 2016.

RODRIGUES, F. et al. Aptidão de híbridos de milho 
para o consumo in natura. Revista de Ciências Agrárias, 41: 484-492, 2018.

RODRIGUES, F. et al. Critérios para a seleção de linhagens de sorgo eficientes e responsivas ao fósforo. Revista Caatinga, 27: 75-84, 2014.

SCHIAVINATTI, A. F. et al. Influência de fontes e modos de aplicação de nitrogênio nos componentes da produção e produtividade do milho irrigado no cerrado. Revista Bragantia, 70: 925-930, 2011.

SCHLEGEL, A. J.; HAVLIN, J. L. Corn yield and grain nutrient uptake from 50 years of nitrogen and phosphorus fertilization. Agronomy Journal, 109: 335-342, 2017.

SILVA, R. G. et al. Potencial genético das populações de milho UFVM 100 e UFVM 200 avaliadas em solos com deficiência de nitrogênio. Revista Caatinga, 21: 22-29, 2008.

SPOLAOR, L. T. et al. Brazilian maize landraces variability under high and low phosphorus inputs. Maydica, 63: 1-8, 2018.

TALABI, A. O.; BADU-APRAKU, B.; FAKOREDE, M. A. B. Genetic variances and relationship among traits of an early maturing maize population under drought-stress and low nitrogen environments. Crop Science, 57: 681-692, 2017.

VAN BUEREN, T. L.; STRUIK, P. C. Diverse concepts of breeding for nitrogen use efficiency. Agronomy for Sustainable Development, 37: 1-24, 2017.

WOLI, K. P. et al. Corn era hybrid response to nitrogen fertilization. Agronomy Journal, 108: 473486, 2016.

ZHANG, H. et al. Large-scale evaluation of maize germplasm for low-phosphorus tolerance. PloS One, 10: 1-13, 2015. 